Purdue University

Purdue e-Pubs

2008

\title{
Tutoring is Real: The Benefits of the Peer Tutor Experience for Future English Educators
}

Janet Alsup

Tammy S. Conard-Salvo

Purdue University, tcsalvo@purdue.edu

Scott J. Peters

Follow this and additional works at: http://docs.lib.purdue.edu/writinglabpubs

\section{Recommended Citation}

Alsup, Janet; Conard-Salvo, Tammy S.; and Peters, Scott J., "Tutoring is Real: The Benefits of the Peer Tutor Experience for Future English Educators" (2008). Purdue Writing Lab/Purdue OWL Publications. Paper 1.

http://dx.doi.org/10.1215/15314200-2007-043 


\section{From the Classroom}

\section{Tutoring is Real: The Benefits of the Peer Tutor Experience for Future English Educators}

\section{Janet Alsup, Tammy Conard-Salvo, and Scott J. Peters}

What does it mean to be a teacher of secondary school writing, and what kinds of activities and internship experiences are most helpful as undergraduate students prepare to become writing teachers? Field experiences or internships have long been a staple of education curricula. In fact, the internship is one part of teacher training during which teacher educators hope they can bridge the all too common ideological divide between university instruction and the perceived "real world" of the secondary classroom. During these clinical experiences, the pre-service teacher is given a placement in a local school and visits a particular classroom over a series of weeks, either observing, teaching short lessons, or in the case of student teaching, taking over the entire teaching load of the mentor teacher. Much has been written about the benefits of such field experiences for pre-service teachers, especially when these experiences are consistent with the theories learned in methods classes (Bullough 1987; Zeichner 1987).

However, to some extent, there is an artificial element to these experiences, even under the best of circumstances. The student aide or student teacher is working in the class of a master teacher who maintains ultimate control over most classroom and curricular decision-making due to administrative and practical realities. While in our experience, middle and high school teachers who work as mentors for field experiences or internships are predominately generous in providing flexibility for pre-service teachers to experiment with different methods, they are, in the end, responsible for the learning 
that goes on in the classroom, and therefore, must retain some amount of control or supervision. The pre-service teacher, even in the best of circumstances, is a visitor, a student who is coming in to practice being a teacher. In the most effective experiences, mentors allow students to experiment with their own lesson plans and management techniques; in the least effective, the pre-service teacher simply acts out a classroom script provided by the mentor.

While we certainly do not wish to suggest that field experiences in secondary schools are not essential for English education undergraduates, we see peer tutoring in a writing center as a useful addition to the field repertoire of pre-service teachers. Peer tutoring, in contrast to some secondary-school based experiences or in-class role plays, is almost certainly a "real" pedagogical experience, one that is not scripted or that exists in the realm of the hypothetical. The tutor works with student writers independently, without the intrusion of a mentor or supervising teacher. While the undergraduate tutors in Purdue University’s Writing Lab have sufficient mentorship and support for their work, they are not trying to carve out space in someone else's pedagogical sphere.

The question remains, how do we most effectively prepare new teachers of writing so that they will be confident, capable instructors of theoretically sound approaches to writing and composing? How do English education programs succeed in such thorough preparation within the existing institutional structure, consisting primarily of on-campus courses and often short-term classroom field experiences? In this article, we discuss the role peer tutoring might play in enhancing the education of pre-service teachers of writing by providing additional, authentic field experiences which reflect constructivist, student-centered philosophies often adhered to in English education 
programs. The three of us are all connected to Purdue University in various capacities:

Tammy is the Associate Director of the Writing Lab, Janet is an English education professor, and Scott is a graduate of the undergraduate English education program and a former Writing Lab Undergraduate Teaching Assistant. We all work in the same building, and due to our mutual affiliations with the English Department we began discussing the benefits of English education undergraduate students becoming writing tutors. The main benefit we could all identify is the addition of real experience with student writers, a sort of additional, authentic, field experience or internship—one that exposes future educators to collaborative learning in a one-to-one setting. The peer tutor is not a "little teacher" assisting the main instructor (Trimbur 1987), nor is he or she roleplaying in an alien environment. Undergraduate tutors create their own relationships with tutees, make independent decisions about how to approach a tutoring session, and must deal with the outcome of the session, whether positive or negative.

In the remainder of this essay, the three of us take turns discussing our respective areas of expertise and our experiences as teachers of writing, writing tutors, or teacher/tutor educators. In the first section, Tammy explains the preparation of undergraduate writing tutors at Purdue University's Writing Lab and the various theories they are taught to implement in real tutoring sessions. In the next section, Janet reviews briefly what she believes the discipline of English education values concerning the preparation of writing teachers and describes how she includes one-to-one conferencing in her own "composition for teachers" course. Finally, Scott, both a former undergraduate English education student and experienced writing tutor, identifies similarities and differences between the foci of the English education program and his experience as a 
peer tutor. He also describes how writing center pedagogy and a student teaching experience can inform each other, increasing productivity and student learning. In the brief concluding section the three of us summarize what we believe to be the benefits of peer tutoring for undergraduate English education majors who are becoming teachers of writing and how English educators and writing center administrators can collaborate to enrich the educational experiences and preparation of new teachers of writing at the secondary level.

\section{Pre-Service Teachers and Writing Center Experience}

Several studies have illustrated the benefits of writing center experience for college-level composition instructors, particularly in helping instructors develop a student-centered composition pedagogy; however, few studies have addressed the importance of writing center work as an authentic field experience that helps form a writing teacher identity for future secondary-level educators. As Janet notes later, the formation of a writing teacher identity is essential as pre-service teachers shift their selfimage from that of student to that of teacher. While the role of teacher and tutor are separate and distinct, writing center work can still serve as a valuable field experience for future educators, one that not only assists in the formation of a writing teacher identity, but one that also allows pre-service teachers to learn and practice collaborative learning pedagogy in a one-to-one setting.

Although scholars in English education and composition studies continue to discuss ways to better prepare future writing teachers, undergraduate English education students themselves are often removed from these pedagogical discussions. Consequently, these students may be unaware of debates concerning appropriate 
educational experiences for would-be teachers. They simply take their classes, often offered in both English and education departments, and do their best to prepare for their future professional lives as middle or high school teachers. While undergraduates at Purdue and other universities may not have much power to make decisions about their coursework, they do have an option that arguably is important to their development as writing teachers. At our university, as in many others, undergraduates can apply to be writing tutors in the Writing Lab. Undergraduates from many different majors apply to be tutors, and English and English education students make up a significant proportion of those applying for tutoring positions. While there are also graduate student tutors at Purdue, the undergraduate tutors play an important role in the Writing Lab, as they tutor many of the students taking the first-year composition class.

The Writing Lab's tutoring practicum course, a two-credit course offered to undergraduate students, is a pre-requisite for students interested in tutoring positions. This practicum, like many others offered by writing centers at various institutions, focuses on theoretical and practical applications of writing center and tutoring theory, and offers personal and professional benefits beyond employment in the Writing Lab. While the practicum course attracts students in engineering and other sciences, the primary groups of students who join the practicum are English and English education majors. Approximately four to six out of ten total undergraduate tutors are English or English Education majors, all of whom have stated that the practicum is beneficial for their future career plans, particularly if they expect to work as teachers or as editors in the publishing industry. In fact, when asked on their application forms to describe the personal and professional benefits of taking the practicum, many students reply that the experience 
would enhance their resumes, help them teach others how to write, and improve their own communication skills. One recent applicant, an English education major, stated, "I want to become an English teacher and this would give me real life experience." (See Denton 1993 for other similar responses related to the benefits of tutor training courses.) Indeed, the tutoring practicum gives students a practical and theoretical foundation for writing center work. The course covers techniques for tutoring writing and strategies for tutoring non-native speakers of English and special-needs students. It addresses contemporary issues such as visual rhetoric and educational technology. Students in the practicum course encounter two foundational concepts of writing center pedagogy_Bruffee's (1984) concept of collaborative learning and Brooks's (1991) focus on minimalist tutoring — which pre-service teachers can later incorporate in various classroom activities and exercises, as well as in a one-to-one setting. For example, as writing center pedagogues are well-aware, minimalist tutoring advocates student agency and that the "student, not the tutor, should 'own' the paper and take full responsibility for it" (Brooks 1991: 2). In many writing centers, minimalist tutoring emerges through the Socratic questioning a tutor uses to learn more about the student's writing assignment and what issues the student wants to address during the consultation, so the tutor can help the student establish an agenda for the session and work toward becoming a better writer. The focus, obviously, is less on the product and "fixing" the text than on the tutor's responses as reader and collaborator. Tutors ask questions so students can make informed choices and come to answers on their own, and while tutors may offer suggestions, students are encouraged to prioritize and decide how best to revise their texts. 
The written assignments in the practicum course challenge students to wrestle with both theory and practice, giving pre-service teachers an opportunity to develop a writing center pedagogy and, by association, a writing teacher identity. For example, students are asked to articulate their pre-existing notions of what writing centers do and discuss how their experiences in the course and in the Writing Lab have changed those ideas. For many students, their experiences in the practicum alter the preconceived notion that writing centers are remedial. When they encounter Bruffee's ideas about collaborative learning, or when they witness collaborative learning and put those principles in action when they tutor, they learn how to help their peers improve as writers (North 1984: 438). Other assignments include creating a visual argument, which allows students to practice a different form of writing that is becoming increasingly popular on college campuses and in workplaces, and a traditional research proposal and paper about any issue relating to writing center theory or practice, either general to all writing centers or specific to Purdue University.

One of the most important components of the course, one which makes this course unique, is that students are required to spend two hours per week in the Writing Lab doing observations, interviews, and mock tutorials. This aspect of the course gives students an opportunity to observe and practice tutoring techniques and pedagogy with actual student writers, and tutors in training are heavily mentored by experienced tutors during this portion of the course. They begin to respond to actual student texts, first by preparing written comments about a sample student essay, and then by engaging in mock tutorials, where they practice tutoring in a controlled situation. Students complete two mock tutorials during the semester on two different types of projects, a traditional 
argument-based essay and a PowerPoint presentation. The practicum student acts as "tutor" while the experienced tutor acts as "client." After each mock tutorial, student and tutor discuss the details of the session, and tutors give constructive feedback and advice.

Students who ultimately work in the Writing Lab have the added benefit of extending their authentic field experience from the hands-on component of the practicum to actual work with student writers. The course provides a controlled environment for practicum students because they work very closely with veteran tutors. They rarely interact with Writing Lab clients independently. However, when English education majors are hired as tutors, they assist students without the intervention of another tutor or supervisor. Tutors are essentially on their own, unless they ask for help from another tutor during a session with a student, and it is this aspect of writing center work that offers such a valuable field experience for future English educators.

Many teachers-in-training have field experiences in the classroom but sometimes do not have the opportunity to work one-on-one with student writers. Working in a writing center setting offers English education majors a field experience based solely on individual interaction, which can be translated to a classroom setting. In a classroom or group setting, minimalist tutoring and collaborative learning techniques can help a teacher motivate students to take ownership of their texts and to see writing as a process. Teachers can model collaborative learning and minimalist tutoring during group sessions or one-to-one conferences with students, which would teach students how to effectively respond during peer review sessions. Tutoring in a writing center presents an ideal opportunity for English education majors to build confidence and techniques that would 
help them shape classroom experiences, which mirror the student-centered pedagogy they learn in education, English education, and composition courses.

Research has shown that experience in a writing center setting can be beneficial to pre-service teachers. As early as 1979, Almasy and England write about the success of their undergraduate English education majors tutoring in their university writing center:

A flourishing and sometimes understaffed writing laboratory program at West Virginia University coupled with the need for undergraduate English Education majors to work with "real students" made it seem natural to utilize the skills of prospective English teachers in our writing laboratory. After our experience in using undergraduates as tutors, we are confident when we say, "It is working."

Other research, primarily done with college-level teaching assistants, suggests that writing center work is beneficial for new teachers of composition because it allows them "to understand student needs and... to practice student-centered theories" (Cogie 1997: 76). Cogie's research offers two case studies of graduate instructors who considered themselves student-centered teachers before working in a writing center. After working in a writing center, these teachers re-assessed their pedagogies and writing teacher identities, embracing a less authoritative classroom approach in favor of "interactive teaching" where teachers can "discover first-hand the causes for an individual student's writing problems" (83). While Cogie's cases pertain specifically to post-secondary educators - as does most of the literature that describes the benefits of writing center work for teachers - the principles remain relevant to teachers in middle 
and high school who are struggling with balancing classroom management needs with developing an effective pedagogy for writing instruction.

Like these and other researchers, we also found the work of undergraduate English education students in the Purdue Writing Lab to be useful professional experience for the pre-service teachers, as well as enriching learning experiences for inexperienced college writers. We believe that tutoring experiences provide English education students with valuable opportunities to enact so-called best practices of writing instruction, including one-to-one conferencing, allowing student ownership of written work, Socratic questioning, and focusing on higher order concerns before lower order ones such as editing errors.

Of course, writing center scholars understand that being a tutor is different from being a teacher. Peer tutoring requires one-to-one interaction, and tutors are often described as coaches, collaborators, or consultants who do not evaluate students' writing in terms of grades, who do not worry about classroom management. Instead, tutors offer questions to encourage students to think about their rhetorical choices and suggestionsnot mandates - about how students can revise their texts. As writing center scholars know, this differs from peer response activities or peer workshop review groups, which many teachers incorporate into their classrooms. Peer respondents often critique or edit an assignment, rather than using "the questioning and explaining stage" that occurs in peer tutoring (Harris 1992: 372).

However, one of the most direct benefits of the tutoring practicum course is that it gives pre-service teachers exposure to writing center pedagogy, which is not addressed directly in any other English or English education course at Purdue, although Janet's 
"composition for teachers" course addresses many goals that complement writing center pedagogy. These common goals include an understanding of the writing process, critical analysis of texts, and the development of strategies for one-to-one conferencing situations. The difference between our tutoring practicum and English education courses is the focus on the tutor's role as peer collaborator and not as instructor. At first glance, this may seem to present a contradiction for English education majors taking a tutoring practicum course; however, the focus on tutoring, as opposed to teaching or classroom management, enriches the students' pedagogical background and practical knowledge of English and composition. Both the tutor training course and the experience of tutoring in a writing center allow students to gain experience with collaborative learning in an environment different from traditional teacher-training field experiences. Although this exposure to writing centers is valuable in and of itself, English education students have the opportunity to later apply this knowledge in their classroom teaching practices (Gadbow 1989). Additionally, many high schools are establishing writing centers of their own, and the knowledge gained in writing centers benefits any future teacher who may be charged with developing, maintaining, or working in a high school writing center.

Another important difference between the tutor and teacher is that while peer tutors are knowledgeable responders, they are also co-learners or collaborators with the student writer, and their role rarely includes that of grader or evaluator. Sometimes this peer status can lead to logistical and ethical issues in the context of tutoring. However, we argue that experiencing this co-learner role helps pre-service teachers as they begin to think about their emerging writing teacher philosophies and how they will structure their future classes. Perhaps due to the peer tutoring experience the new teachers will feel 
more comfortable in a student- or writer-centered classroom in which the teacher and peers both respond to written work and provide valuable feedback for revision. While the teachers will inevitably assign a grade, perhaps they will be able to create classroom spaces that are more democratic and collaborative.

Students who take the practicum course for undergraduate writing tutors at Purdue University learn strategies for dealing with a variety of learning styles, and secondary school teachers can use many of these same techniques in a classroom environment. Such strategies, which are familiar to writing center tutors and administrators, include reading text aloud-either by the student or the tutor in a consultation—which allows writers to hear and correct problems they overlook when reading text to themselves. Tutors often use mapping or outlining techniques to help students brainstorm and organize their ideas, and some tutors use highlighters and markers to show students ordination and subordination of ideas. These strategies encourage tutors and tutors-in-training to consider a student's learning and writing styles. Another benefit of the practicum course is that it addresses strategies for working with non-native speakers of English, an area of concern for educators regardless of level or subject area. While the tutoring practicum does not adequately address all issues of working with English language learners, it does give students an overview of issues such as contrastive rhetoric, tutors serving as cultural informants, and the need to be culturally sensitive when working with international students. Students are learning about these issues in the context of a writing center, but much of this knowledge applies to any educational setting and would thus be beneficial to students in English education. In the past, some of the mock tutorials and student paper response activities dealt specifically 
with assignments written by non-native speakers of English, allowing students to apply their knowledge of tutoring and working with English language learners to a specific real-world context.

Finally, future teachers who wish to make collaborative learning a pedagogical focus in their classrooms may take the tutoring practicum and have the advantage of experiencing first-hand how collaborative learning works in a non-classroom setting. They can then incorporate collaborative learning and writing activities in their classrooms by requiring group projects or peer tutoring or including one-to-one conferencing with students as part of a class assignment. Tutoring teaches pre-service instructors to improve their own responses to their students' drafts, helping them to focus their comments on open-ended questions that help students consider rhetorical choices rather than comments that are vague or editorial in nature (Van Dyke 1997: 3). In summary, writing center work is unique among field experiences for pre-service teachers, and the experience seems to provide unique learning opportunities for young writing teachers that cannot be easily duplicated in traditional field experiences or internships.

\section{English Education and the Teaching of Writing Teachers}

The discipline of English education, as well as the educational process of becoming an English teacher, is undoubtedly complex and wide-ranging. Middle and high school English teachers are expected to teach many things in their various courses, including, of course, literature, reading, grammar and language, and, more recently, media studies. Additionally, the teaching of writing, or composing, is central to the work that secondary school teachers do, and, therefore, pre-service English teachers must be prepared to teach writing effectively and also must be strong, capable writers themselves. 
There are various ways pre-service English education students become competent writers and teachers of writing, including university coursework, internships with master teachers, reading and research in the discipline, and work with professional organizations such as NCTE and the National Writing Project. However, sometimes, despite the best efforts of English educators and university-level compositionists, writing is relegated to the back burner in secondary classes, becoming a second-class citizen in a pedagogical world dominated by literature.

As noted earlier, undergraduate English education students at Purdue University often opt to become writing tutors, even though these students also have field experiences in local secondary schools each year and a culminating ten-week student teaching internship built into their programs. At Purdue, the Writing Lab is housed in the English Department, so English education students have ready access to the physical site of the Lab, and they are often familiar with its inner workings because of regular workshops the Lab hosts in its facilities. Since our English education program is a joint program shared by the English and Education Departments, collaboration between the programs seems natural, and is perhaps easier to achieve than at universities where English education faculty are housed completely in schools of education, which are most often physically separated from English departments and, in the worst of cases, ideological and philosophically at odds with them. All too often, and as is noted in the work of many English educators and composition scholars (Thompson 2002; Tremmel and Broz 2002) the worlds of "English" and "education" are distinct and divided within institutional settings and, therefore, in the intellectual lives of teachers in training. While we understand and applaud that many post-secondary schools have successfully closed the 
gap, this scholarly divide, when it still exists, can lead to philosophical conflict as new English teachers move into their own classrooms and begin to make pedagogical decisions. Do they teach as they were taught in English education methods courses or do they model the pedagogies they experienced in classes as a student? Do they focus on teaching literature and writing about literary texts, or do they also ask students to write in various other genres for a myriad of other purposes? In essence, how do they come to understand the differing philosophies of writing instruction as enacted by academics within different disciplines?

To help English education majors begin to address such questions, I regularly teach a course called "composition for teachers" which is taken by all English education majors. When I teach the class, I list the following goals on my course syllabus:

- To understand the nature of the writing process and how it can be taught effectively to secondary students

- To understand and practice critical analysis when reading and responding to student and peer texts

- To understand the history of the teaching of writing in American public schools and how it has evolved to its present state

- To understand and be able to effectively apply recent and theoretically sound approaches and philosophies when teaching writing

- To develop skills in teaching writing in one-to-one conference situations [emphasis added]

- To understand how teachers can address issues of race, class, gender, and ethnicity through writing in the classroom 
In summary, in teaching a course in writing pedagogies to English education students, my goals are twofold: 1) to help students experience the writing process and continue to discover/think about themselves as writers and 2) to teach students composition and pedagogical theories/methods to effectively teach writing to their secondary school students.

As the italicized goal above indicates, I spend several class days discussing the benefits and challenges of "teaching writing one-to-one," to use the phrase coined by Muriel Harris (1986) and how pre-service teachers might go about integrating one-to-one writing conferencing in their future secondary school classes. While I recognize that a teacher individually conferencing with students is not the same as peer tutoring, it is often its pedagogical equivalent in secondary classes. However, conferencing with individual students can be pragmatically difficult for the middle or high school teacher who might teach as many as 150 students each day. Simply convincing pre-service teachers that they will have the time to do the kind of conferencing they see going on in a university writing center is a challenge. However, much research has demonstrated the benefits of one-toone writing conferences for the learning of the instructor or tutor as well as the student (see Devin-Sheehan, Feldman, \& Allen 1976; Dansereau 1988). To help pre-service teachers see conferencing as something possible as well as desirable, I ask them to read portions of Harris' book, Teaching One-to-One: The Writing Conference, which contains many suggestions for how conferences might be approached and then role-play some specific strategies for conferencing with students. We usually start by practicing a version of Donald Murray's classic response format from A Writer Teaches Writing (1985: 158), which begins with the student commenting on the draft, continues with the teacher's 
response to the draft and student comments, and ends with the student's response to the teacher. One of the key characteristics of this conference pattern is that the student writer always speaks first and therefore guides the conference discussion. In this way, preservice teachers can begin to see that the preparation for individual conferences isn't necessarily time consuming or extensive. Afterward, I ask students to role-play other types of conference formats, such as responding with a diagram, map, or picture as student writers read their texts and the so-called "question conference," during which the teacher can only ask questions of the students rather than give didactic advice. Last, we discuss various questions that a teacher might ask a student during a writing conference, which range from "What works best in this draft?" to "How is this text different from what you expected?" This mock conferencing has two overall goals: first, to help preservice teachers build a repertoire of strategies for assisting student writers which are built upon a student-centered, process-oriented philosophy, and second, to help them more fully understand the writing process itself, its reciprocity, its complexity, and its variety.

Research demonstrates that when there is a great deal of inconsistency between pre-service teacher experiences in the field and instruction provided in the methods classroom, young teachers will often opt either to enact practices they have experienced themselves and liked as students, or practices mentor teachers in the schools promote because those teachers are currently in the trenches, unlike their university professors (see Bullough 1987; Zeichner 1987; Alsup 2006). Both of these choices are often relatively unreflective and based on personal experience alone, more than a combination of personal experience, study, and reflection. Therefore a lack of theoretically sound, 
active, and ongoing field experiences or internships can complicate a pre-service teacher's education by causing confusion and ideological tension that sometimes cannot be easily resolved. The experience of being a writing tutor might provide another opportunity for pre-service English teachers to successfully enact the theories and methods they learn in their courses and read about in pedagogical texts. Being a tutor might be yet another stepping stone to moving from the primary identity of "student" to that of "teacher," without sacrificing either personal philosophies about learning to write or university instruction. While different in many ways from the one-to-one writing instruction that goes on in a secondary school classroom, the university tutoring experience can provide real-life, independent experience to cultivate feelings of comfort and confidence as a writing teacher who can both provide full-class instruction and mentor students one-on-one. In the following section, Scott provides a first-hand account about his experiences as both tutor and pre-service teacher, and how his work in the Purdue Writing Lab has helped to shape his identity as writing teacher.

\section{Perspectives on Peer Tutoring from a Pre-Service Teacher}

As Tammy mentioned previously, by far the largest number undergraduates enrolled in the tutor-training course are in the disciplines of English and English education. When I decided to become involved with the Purdue University Writing Lab, I saw that both my academic program and the writing center were linked, at least partly in style and ideology. After all, a common goal of instructors and tutors is to help students become better writers. After completing a long tenure in both programs, I can see more areas of connection between English education and writing center work. 
The field of education, possibly more than any other profession, requires field experiences. Students watch an example classroom, and they work hands-on, as demonstrated in education literature and research (Dewey 1989 [1938/1963]; Knowles and Holt-Reynolds 1991). One problem is that field experiences can lack fullness as authentic experiences. My fellow English education graduates and I entered another person's classroom to teach his or her students—not taking over our own classrooms. Student teaching is, undoubtedly, a great learning experience, but perhaps the English education curriculum can go further in preparing new teachers. As Tammy and Janet mention, both education pedagogy and writing center theory address helping students with special needs, interacting with ESL learners, teaching the writing process, applying theory to practice, and something I see as the definition of a future educator: being able to wear many hats and adapt to different types of students and situations.

Working with non-traditional students, learning disabled students, or ESL students is often a challenge in either setting. When student teachers observe in the classroom and have a problem, they go to their mentor teacher or talk to their professors about it. When tutors have a problem or challenge in the writing center, they must often work through it, as a normal teacher must, although tutors are mentored and have access to resources in a writing center. In short, tutoring cuts the umbilical cord. This lack of an immediate safety net is what makes tutoring such an authentic experience

I admit that simply being thrown in the water and told to swim does not sound like the greatest of all pedagogical approaches. I have to say, however, that it has afforded me many opportunities to learn and grow as a teacher. In one tutorial, for example, a student from Asia brought in an assignment focusing on a campus 
community. In his essay, this student did a great job describing a university bowling league. The problem was his presentation of the information and his grammar. As a secondary education teacher, I did not receive a good deal of practical instruction on teaching grammar. I was taught the theory behind the practice, but was never provided with advice about how exactly to explain to an eighteen-year-old student how to make his pronouns and verbs agree. I learned my best approaches for handling such situations in the Writing Lab. Rather than trying to teach him the ins, outs, and whys of American syntax and semantics, I chose to go with a more student-centered approach that allowed him to fix his own mistakes. By simply reading the sentences aloud and creating a corresponding chart of the possible pronouns, the student was able to fix many simple errors. I learned this strategy in the writing center and later applied it during a full time student teaching experience, learning that a student centered approach maintains the individual's ownership over the paper.

During my student teaching, I used a large number of ideas I learned in the Writing Lab, and I was able to enact these strategies in the secondary classroom. For example, I developed a diagram that helps explain to students how a paper tends to start out more general, move to the specific throughout the body, and then transition again to the general through the closing. I often referred to this diagram in tutorials. Similarly, during my student teaching I began several lessons on persuasive and descriptive writing by referencing this diagram in order to give students a larger contextual frame of reference. In the end, I think the diagram works better in the secondary school than at the college level because younger students can benefit so greatly from concrete images and visual representations. 
During my student teaching I applied many more moves from my Writing Lab playbook, especially when teaching a unit on writing a persuasive essay. While in the writing center, I noticed many students still have trouble grasping some of the more complex ideas of persuasive writing, especially the concept of a concession. I once worked with a very strong writer who had political opinions quite in contrast to mine. Helping her was simple, since I literally embodied the argument to which she wanted to concede. Because of this experience and many more like it, I was able to see the value in teaching the concept of concessions to secondary English students. During my student teaching, my students and I spent two class periods looking at examples and working on including concessions in order to strengthen an argument. Once again, the occurrences were not identical, but I strongly believe that the experiences I had in the Writing Lab positively influenced my student teaching experience and the quality of my early teaching. They also showed me the importance of using student examples to make the paper more accessible and individualized.

One of the most interesting examples of a theory discussed in education classrooms and witnessed in writing centers is the application of a writing process by real students. In contrast to education students, tutors actually see students move through all stages of their respective processes. These writing processes are so individualized that I, as a tutor, have almost no generalized expectations when going into a session. Students may have nothing but an idea, or they may have a third draf. I feel confident that I can help either student. Even the best student teaching experience with over one hundred students will not equal the experience of interacting over several years with scores of 
tutees. Once again, the writing center went the extra step and offered me years of direct application and broadened my experience.

By applying minimalist tutoring strategies, we as teachers and tutors can do several things. We can motivate students and get them to see their own writing process as a collaborative event. Strictly from a teacher's standpoint, this will also keep us from having to read every student paper and comment extensively on its correctness. Any future educator will only receive minimal experience in responding to writing during their education coursework. This is no fault of the program, rather just a byproduct of not having the actual papers and students to respond to in authentic situations. However, as Irene Clark (1988: 348) writes, the "Writing Center experience.... enables new composition instructors to gain important insight into the use of teacher response and its effects on the delicate situation which exists between teacher-suggested revision and the student's own ideas" (348). Not only does the writing center allow for practice in responding to student papers, it also focuses the feedback and encourages student ownership of writing.

To say that both being a tutor and being a teacher requires the same type of expert feedback would be inaccurate. Teachers are ultimately charged with evaluation as opposed to the peer feedback given by tutors. However, future educators can learn to take a step back and make additional efforts at maintaining student ownership of any assignment. Patricia Rizzolo (1982: 117) points out that one of the largest challenges to any new tutor, and we would argue to a new teacher as well, is functioning as a "learning facilitator and not a proofreader." Of course, teachers need to give instruction on grammar and usage; however, the focus should be placed foremost on higher order 
concerns. Writing center tutors "provide feedback on the communicative effectiveness of the text" (Clark 1988: 649); they do not judge or evaluate the text. When in the context of the classroom, the teacher is supposed to know all—as far as the student is concerned. Sadly, too many teachers accept this teacher-as-supreme-authority identity due to narrow institutional demands and expectations. In the worst-case scenario, we as teachers simply become used to answering questions and grading papers as relatively autonomous evaluators. These activities often do not lend themselves to questioning or collaboration with our students. However, in the Writing Lab these two actions are paramount over all else.

Often, the fields of English education and writing centers have little in common when it comes to evaluation, at least not in everyday practice. In a typical tutorial, the tutor almost always starts out with questions, not evaluative comments. This is not only an attempt to find out basic information, but it also gets the student involved with the revisions. If students can see that they are the experts on their papers, they should at the very least be more inclined to take serious ownership of their work. While we fully acknowledge the exigencies of grading in the secondary classroom, and standardized assessment as conducted through state exams and, most recently, the SAT writing exam, we also believe that these evaluative tasks are possible while maintaining a more comfortable, collaborative atmosphere. To take the argument even further, we believe the pedagogical strategies learned by tutors can improve the performance of student writers on these ubiquitous, high-stakes assessments.

My personal experience as a teacher and tutor has provided me with many opportunities to experiment with collaboration. Before I even sit down with tutees, I 
introduce myself, ask them their names and majors, make some kind ice breaking comment, and finally, get down to asking questions about their assignments. I still do this in the classroom as well. As said before, this not only informs me as a "teacher," but it also gets the student to feel more comfortable with the entire situation. Only after students have explained the assignments of their papers in their own words do I even look at the paper for the first time. Often my first act will be taking the paper, turning it over, and asking the student to tell me about what he or she is writing. I do this to see if what a student has stated on paper matches what he or she has said out loud. In my experience, students can almost always explain their position better than they can write it. This was proven in my experience when I applied such a practice to my student teaching students. Not only did this make the students' ideas clearer to me, but they became clearer to the students as well.

One of the few things that must happen in every tutorial is the setting of an agenda and deciding what needs work. Ideally, every tutor will first ask the students what they would like to address; however, many times students aren't even sure what's wrong. While education students discuss what parts are the most important in student writing, this doesn't become important until the future teacher is attempting to help a student revise his or her paper with one hundred more students to go. The idea of higher and lower order concerns might not be called as such in the secondary classroom, but they can definitely improve the teacher's efficiency and quality of feedback.

Simply knowing how to adapt to a given educational situation is so basic that it might be the most important skill for a future teacher to learn. Teachers must wear many hats and be able to alter lesson plans, instructional strategies, and even classroom 
management procedures for every class and sometimes even for every student. This student-centered focus could not be more emphasized in the writing center. Everything about one-to-one tutoring works against a fixed formula for helping students. While adaptation for individual student needs is discussed in education courses, the best way to experience hands-on instructional differentiation is through authentic experiences.

The notable contrast between peer tutoring and English education field experiences comes in the area of pragmatics. While both yield positive benefits, the educational observation can still only be an observation and not an overly authentic experience. In such situations, future English educators can gain insight from acting as a peer tutor at their university. Tutoring is real. There is no supervisor or mentor teacher coordinating a tutorial session, and each individual session is geared toward creating a better writer. While I make no hard-and-fast claims that educators with peer tutoring experience are inherently better teachers than those who don't have such experience, I do believe such experience is extremely beneficial.

\section{Benefits of Peer Tutoring for Pre-Service English Teachers}

An English education student in an article written by Norma Decker Collins (1993: 7) states, "I think working in the writing center is the most useful thing I've done in all my college days. This is an excellent place to put the things you are learning to actual use. It is different than when you memorize the material the teacher tells you you'll need when you have your own class." This student sums up all the major benefits of the writing center. Such a place provides direct application of educational theories and writing pedagogies. 
As is clear in the student above, it is essential that new secondary English teachers develop teacher identities. In short, the students must begin to think of themselves as teachers of writing, in addition to teachers of grammar or literature. Writing center and tutoring theory is consistent with many of the constructivist, critical pedagogies we encourage in English education courses, and the experience of tutoring itself allows additional real-life enactments of these philosophies. Harris (1992: 380) describes the role of a tutor as a

hybrid, somewhere between a peer and a teacher, who cannot lean too much one way or the other. Suspended with a foot in each discourse community, tutors perform a valuable service for their students. Since tutors speak with words students recognize and understand, they act as interpreters for those bewildered by the critical vocabulary of teachers.

As peer tutors, English education students experiment with multiple expressions of a teacher identity, expressions which are both authoritative and nurturing, roles which are alternatively adopted by effective classroom teachers as instructional contexts demand.

Peer tutoring in a university writing center is not the same experience as conducting one-to-one writing conferences with secondary school students. The secondary school teacher is no longer a "peer," as is the undergraduate English education tutor; instead, he or she has become the teacher. However, even if we view one-to-one conferencing as the nearest equivalent to tutoring the new teacher can enact in the classroom (with the exception of teaching secondary school students to tutor each other), it is not always practical in a secondary school setting due to time constraintsconferencing individually with 150 students is not always possible. However, the 
knowledge that secondary teachers in training can gain through peer tutoring during their university careers is transferable and ultimately helpful. They often gain a richer teacher identity, a better-developed philosophy of teaching writing, added confidence, and increased ability to use language to talk about writing. In fact, taking on or translating the role of tutor for use during interactions with their own students might be one way teachers can help adolescents understand the complex rhetorical situation of writing testing and thereby strive to be more sophisticated, versatile writers than the tests seem to require.

While we have outlined many benefits for English education majors who gain experience in a writing center setting, the reality is that not all future educators have the opportunity to have such an experience. At Purdue, the tutoring practicum course is capped at twenty students, and it is open to all undergraduate students regardless of major. In addition, just one section of the course exists, and it is only offered in the fall semester. During the last recruitment period for the practicum course, thirty students applied, and logistically it would be impossible to allow every English education major to enroll. According the Purdue College of Liberal Arts Advising Office, 168 students have identified as English education majors for the fall 2005 semester. Furthermore, since there is no guarantee that a student in the practicum will be hired as a tutor, not all English education majors will have an authentic field experience beyond the course itself. Nevertheless, we argue that English education majors who have had the opportunity to take the practicum course and tutor in the Writing Lab have found the experience to be directly applicable to their work as future educators. 
We believe this article demonstrates how the all-too-common secondary/postsecondary divide might be bridged through the work of English education students as undergraduate tutors in an English Department sponsored writing center. By bridging such a disciplinary divide, English education undergraduates are able to enrich their teacher education with a greater breadth and depth of knowledge about composition and pedagogical theory as well as engage themselves in additional field or practicum experiences that allow them to work independently with student writers.

Despite what we see as a self-evident connection between peer tutoring and enhanced teacher education, we are not arguing that people outside of English education cannot benefit from positions as peer tutors, nor do we assert that English education students who do not tutor cannot be excellent teachers. We have seen people from engineering, the health sciences, business, and other areas of the humanities, in addition to English education, become successful as peer tutors. Research has shown the benefits of writing center work for post-secondary composition instructors (See Collins 1982-is this the right Collins?; Harris 1986; Neuleib 1978; Simpson 1985; Rottenberg 1988; Zelenak, et al 1993; Jackson 1994, among others), but while our experience has taught us that writing center experience offers unique benefits for students in English education, little research exists to show the connection between writing centers and undergraduate pre-service teacher preparation. We suggest that this is a research area that the fields of English education and writing center theory could explore in more depth. Despite our different institutional roles and experiences (professor, associate director of a writing center, and former undergraduate student), each of us recognizes the pedagogical 
possibilities of peer tutoring. For us, tutoring is real, with real benefits for future secondary English teachers.

\section{Works Cited}

Almasy, Rudolf, and David England. 1979. "Future Teachers as Real Teachers:

English Education Students in the Writing Laboratory." English Education 10.3: 155-62.

Alsup, Janet. 2006. Teacher Identity Discourses: Negotiating Personal and Professional Spaces. Urbana, IL \& Mahwah, NJ: National Council of Teachers of English/Lawrence Erlbaum, Associates.

Brooks, Jeff. 1991. "Minimalist Tutoring: Making the Student Do All the Work." Writing Lab Newsletter 15, no.6: 1-4.

Bruffee, Kenneth. 1984. "Collaborative Learning and the 'Conversation of Mankind.' College English 46, no. 7: 635-652.

Bullough, Robert.V. 1987. "First Year Teaching: A Case Study." Teachers College Record 89, no. 2: 39-46.

Clark, Irene L. 1988. "Preparing Future Composition Teachers in the Writing Center. College Composition and Communication 39, no. 3: 347-350.

Collins, James L. 1982. "Training Teachers of Basic Writing in the Writing Laboratory." College Composition and Communication 33.4: 426-33.

Collins, Norma Decker. 1993. “The Role of a Writing Center in a Teacher Education Program." The Writing Lab Newsletter 18, no. 4: 6-7.

Cogie, Jane. 1997. “Theory Made Visible: How Tutoring May Effect Development of Student-Centered Teachers.” Writing Program Administration 21, no.1: 76-84. 
Dansereau, Donald .F. 1988. "Cooperative Learning Strategies." In Learning and Study Strategies: Issues in Assessment, Instruction, and Evaluation, eds. Claire E. Weinstein, Ernest T. Goetz, and Patricia A. Alexander, 103-120. Orlando, Fl: Academic Press.

Denton, Thomas. 1993. "Peer Tutors' Evaluations of the Tutor Training Course and the Tutoring Experience: A Questionnaire.” Writing Lab Newsletter 18, no. 3: 14-16. Devin-Sheehan, Linda, Feldman, Robert S., and Vernon S. Allen. 1976. "Research on Children Tutoring Children: A Critical Review." Review of Educational Research, 46, no. 3: 355-385.

Dewey, John. 1989 [1938/1963]. Experience and Education. 1989. New York: Macmillan.

Gadbow, Kate. 1989. "Teachers as Writing Center Tutors: Release from the Red Pen." Writing Lab Newsletter 14, no. 4: 13-15.

Harris, Muriel. 1986. Teaching One-to-One: The Writing Conference. Urbana, IL: National Council of Teachers of English.

Harris, Muriel. 1992. "Collaboration is Not Collaboration is Not Collaboration: Writing Center Tutorials vs. Peer-Response Groups." College Composition and Communication 43, no. 3: 369-383.

Jackson, Alan. 1994. "Writing Centers: A Panorama to Teaching and the Profession." Writing Lab Newsletter 18, no. 6: 1-2, 12.

Knowles, Gary J., and Diane Holt-Reynolds. 1991. "Shaping Pedagogies Through Personal Histories in Preservice Teacher Education. Teachers College Record 93, no. 1: 87-113. 
Murray, Donald. M. 1985. A Writer Teaches Writing. Boston, MA: Houghton Mifflin, Neuleib, Janice. 1978. "Training Potential English teachers in the Writing Center." Writing Lab Newsletter 3, no. 8: 2-3.

North, Stephen. M. 1984. “The Idea of a Writing Center.” College English 46.5: 433-46.

Rizzolo, Patricia. 1982. "Peer Tutors Make Good Teachers." Improving College and University Teaching 30, no. 3: 115-119.

Rottenberg, Annette. 1988. "Learning to Teach by Tutoring." Writing Lab Newsletter 12, no. 10: 11-12.

Simpson, Jeanne. 1985. "Defining the Status of Writing Center Tutors.” Writing Lab Newsletter 9, no. 6: 4-6.

Thompson, Tom. 2002. Teaching Writing in High School and College: Conversations and Collaborations. Urbana, IL: National Council of Teachers of English.

Tremmel, Robert and William Broz. 2002. Teaching Writing Teachers of High School English and First-Year Composition. Portsmouth, NH: Boynton/Cook.

Trimbur, John. 1987. "Peer Tutoring: A Contradiction in Terms?" The Writing Center Journal 7, no. 2: 21-8.

Van Dyke, Christina. 1997. "From Tutor to TA: Transferring Pedagogy From the Writing Center to the Composition Classroom." The Writing Lab Newsletter 21, no.8: $1-3,10$.

Zeichner, Kenneth. 1987. “The Ecology of Field Experience: Toward An Understanding 
of the Role of Field Experiences in Teacher Development." In Advances in

Teacher Education, Vol. 3, eds. M. Haberman and J. Backus, 28-34. Westport, CT: Greenwood.

Zelenak, Bonnie, Irv Cockriel, Eric Crump, and Elaine Hocks. 1993. "Ideas into Practice: Preparing Composition Teachers in the Writing Center." Journal of Developmental Education 17, no. 1:28-34.

\section{Vectoring Genre and Character: A Pedagogical Model for Chaucer's Troilus and Criseyde and Other Multi-Generic Texts}

\section{Tison Pugh}

As with many of the finest pieces of literature, Chaucer's Troilus and Criseyde dazzles its devotees with its brilliance, but this brilliance bears the potential to blind even the brightest of our students. As I recall from my own experiences as a student reader, it is an incredibly difficult text to confront for the first time. With its mix of sources from "Lollius" to Boccaccio, its at times contradictory themes of love, religion, honor and truth, its complex range of classical allusions, and its multiple generic forms, Troilus and Criseyde is a work of magnificent scope and intimidating breadth. Combine this panoply of critical issues with the difficulty that many undergraduate students face as novice readers of Middle English, and a daunting pedagogical task ensues for professors of Chaucer's literature.

A strategy that I have found effective for addressing this potentially overwhelming pedagogical task is to ask students to analyze the relationships between 
genre and other constituent features of the text. Through this process, I encourage students to engage in vectored analysis, which I describe as the examination of a text from at least two converging yet separate perspectives; it entails finding complementary aspects of a text and analyzing how they function together to generate textual meaning. Many students approach me with ideas for their essays that focus primarily on one overwhelmingly large topic (e.g., a feminist analysis of the Wife of Bath, a study of chivalry in Sir Gawain and the Green Knight), and I remember writing such singularly focused essays as an undergraduate myself, including such gems as "Birds in Romantic Poetry" (B+) and "The Symbolism of Books in Oliver Twist" (A-). Encouraging students to examine literature from complementary and vectoring perspectives enables them to make the cognitive leap from a static analysis of one issue to a more vibrant exploration of textual interplay. Of course, advanced students often make these analytical leaps for themselves, but vectored analysis provides a pedagogical foundation for students of all abilities to approach multigeneric texts and to reach deeper insights about them. Furthermore, I believe that this approach could be successfully reformulated for a range of multigeneric texts. In the following analysis, I focus my attention on Troilus and Criseyde, but specialists of other authors and literary periods should readily be able to adapt this pedagogical strategy to their own unique needs.

Genre lays the foundation for this pedagogical strategy, and I typically use character as the complementary field of analysis. A range of other perspectives could provide the complementary thrust of the vector, but for the purpose of this essay, it will be helpful to elucidate this pedagogical strategy with both converging components of the vector clearly demarcated. These two narrative structures, which undergird so many 
literary texts, provide students with critical tools to analyze issues of deep complexity. In terms of classroom praxis, introducing a text's genre often provides an effective starting point for teaching virtually any piece of literature. (For studies of genre, see Dubrow1982; Todorov 1990; Derrida 1992; Beebee 1994; Barr 2000; Duff 200; and Devitt 2004). As Rosalie Colie (2000: 166) argues, genres and patterns structure human perception by training the mind to search for them: "patterns, kinds, mental sets organize for us the lives we individually lead, much as these kinds, sets, patterns organized the vast body of literature. Experience can be seen as searching for its own form, after all: the kinds may act as myth or metaphor for a . . new vision of literary truth." With this definition, Colie points to the ways in which genres structure lives as well as literatures. As readers become more critically attuned to the nuances of literature, they begin to discern the ways in which certain texts' shared characteristics construct a particular literary form. By focusing on the ways in which readers experience a form of literature, professors can lead their students to a deeper understanding of the circularity of literature and literary creation, in which writers and readers dialectically respond to genres through the disjunction between the expectations of a given genre and a representative text under consideration.

In an earlier essay, I described the utility of such a generic approach for Chaucer's Canterbury Tales, in which the first step in teaching each tale is to introduce students to the expectations of its genre and then to explore the faultlines between the particular tale and its ostensible genre (Pugh 2002: 45-47). By analyzing a text's generic structure and the ways in which Chaucer plays with, frustrates, and at times adheres to typical generic expectations, the reader realizes that genres establish expectations that authors playfully 
deconstruct. This approach is helpful for the Canterbury Tales but less applicable to Troilus and Criseyde due to the simple fact that Troilus and Criseyde cannot be meaningfully captured by a single genre. Certainly, we could ask our students to investigate the genre of Troilus and Criseyde, but such a large question for such a complex text is perhaps beyond the scope of most undergraduate courses--if not of graduate courses as well. A twenty-page essay might begin to scratch the surface of a compelling answer, but it is difficult for me to imagine such an issue being addressed in sufficient depth to reach a persuasive conclusion in a five-to-seven or even a ten-totwelve page essay. Such an assignment risks facile analysis and selective reasoning, as the vast scope of Troilus and Criseyde would allow students to pick the evidence to support their positions while breezing past the textual moments that either trouble the narrative's relationship to a particular genre or set it in dialogue with other genres.

Due to Troilus and Criseyde's debts to a range of genres--including romance, epic, tragedy, and comedy but also fabliau, history, lyric, and allegory--any pedagogical approach to the text should address rather than overlook how these multiple genres function together. (For a review of the generic traditions in Troilus and Criseyde, see McAlpine 1978 and Windeatt 1992: 138-79.) These overlapping and at times contradictory genres create the text's stunning perplexity and mystery, as they also undermine the formulation of a unified understanding of it. For example, one could read Troilus and Criseyde as a romance and explore its tricky relationship to this genre, but such an approach is somewhat limited in its view because, by foregrounding one genre, the other genres at play in the text are relegated to a secondary position. Such an approach is rather like looking through a kaleidoscope frozen to one static image: the 
view might indeed be stunning, but it is, all the same, only one view. For Troilus and Criseyde, then, genre is a slippery hermeneutic, useful for asking critical questions of the text but through its multigeneric play refusing to provide a firm foundation for analysis.

Furthermore, if professors concentrate classroom analysis primarily on one genre of Troilus and Criseyde, they strip the text not only of its deep complexity but of some of its pleasure as well. As Roland Barthes (1975: 30-31) points out, the multiplicity of generic forms and the concomitant destruction of a single and monolithic genre is a key feature of the pleasureful text: "First, the text liquidates all metalanguage, whereby it is text; no voice (Science, Cause, Institution) is behind what it is saying. Next, the text destroys utterly, to the point of contradiction, its own discursive category, its sociolinguistic reference (its 'genre')" (original emphasis). By destroying genre as a singular signifier and refracting Troilus and Criseyde through a generic prism, Chaucer anticipated Barthes's observations regarding the destruction of genre and the resulting pleasures of the text. Focusing on a single generic hermeneutic strips Troilus and Criseyde of some of its narrative pleasure, which seems an unnecessarily ascetic approach to an insistently pleasureful text. With multigeneric texts, one should investigate this exuberantly cacophonous play of genres rather than analyzing the text exclusively from one generic perspective.

If genre is a somewhat unwieldy classroom hermeneutic for Troilus and Criseyde, teaching it through its characters elicits pedagogical problems as well. Foremost, character analysis in many ways may appear somewhat passé, possibly because it brings to mind a form of unsophisticated analyis ("Did you like this character? Why or why not?") that some scholars might deride as dilettantish and book-clubbish. Characters 
nonetheless structure narratives: most narratives have at least one, and the primary character often serves as the reader's vantage point through which to observe the plot's unfolding. (Key studies of character in literature include works by Forster 1927; Cixous1974; Cohn 1978; Price 1983; Rorty 1988; Phelan 1989; and Lynch 1998.) Elizabeth Fowler (2003: 28) defines character in relation to fields of social practice; it is "the literary representation of person. ... [It] is a dominant model of person that has grown out of a social practice--a practice that has its own institutions, behaviors, artifacts, motives, social effects, audiences, and intellectual issues.” By connecting characters to the particular social worlds from which they arise, Fowler asks readers to view literary characters as vibrant embodiments of a range of environmental factors. Through her dynamic view, literary character emerges as a critical nexus of text and culture, and a fertile field for critical analysis. Similar to genres, which arise from shared conventions among various texts, so too do characters frequently share a range of actions, behaviors, and emotions.

In terms of classroom analysis for a text like Troilus and Criseyde, character offers problems similar to genre: it is simply so vast a topic of analysis that students can overlook details and stage responses that are slick yet unconvincing. As Peter Parisi (1979: 60) laments,

When asked, for example, about character motivation or the effect of some detail, [students] come up with bright-eyed hypotheses that might fit some story somewhere, but arise from the one at hand only by free association grounded in logical probability or past experience. In other words, our 
students seem capable of offering us hypotheses and deductions in place of close attention to the text.

Surely every professor who teaches Troilus and Criseyde has witnessed such selective evidence gathering in discussions of Criseyde and her decision to remain with Diomede and the Greeks rather than to return to Troilus and the Trojans: her defenders point to her powerlessness in her position; her critics highlight her agency and her choices. The poem itself refuses to disallow either reading, and so the debate rarely moves beyond the restating of previously held positions. Surely these intriguing characters merit deep study, but professors need to ground this analysis with a hermeneutic that meaningfully focuses the students' attention to issues that do not readily devolve into "analysis" of the "he said, she said" variety.

For multigeneric texts of such scope as Troilus and Criseyde, daunting hermeneutic and heuristic problems impede using either genre or character as pedagogical tools. The sheer multiplicity of genres and the vastly conflicting motivations of the characters throughout the approximately 8000 lines of Middle English poetry raise questions of such depth and complexity that both of these approaches risk stultifying oversimplification of a brilliantly complex text. Surprisingly, despite the pitfalls of genre and character analysis as individual hermeneutics, their union creates a variety of interpretive vantage points into the text that are more supple and pedagogically useful than either approach alone, at least in regard to my own experiences in the classroom. By encouraging a vectored approach that uses genre as a foundation from which one can also ask questions about character, professors can open up Troilus and Criseyde to a range of interpretations that their students develop by themselves. 
It might appear that combining genre and character into a joint hermeneutic would multiply the difficulties of using either one separately, but paradoxically, their union creates a hermeneutic that allows deeper precision than either approach used separately within the temporal limitations of most classrooms. The process entails asking students to see the relationship between a given character and multiple genres and the ways in which the character embodies--or fails to embody--the expectations of these genres at given moments throughout the text. Thus, as Fowler asks readers to see the interconnections between characters and social practice, professors can ask their students to see the interconnections between characters and the coded expectations of various genres. Characters grow out of social practice and institutions, and genres are likewise such a formative constituent of character creation: certain recognizable types of behaviors and actions are aligned with the various characters that inhabit a particular generic landscape. In this manner, it is apparent that character and genre are not separate perspectives into a text but that they are circularly intertwined: certain genres require specific characters, and certain characters typically structure specific genres.

The first step in teaching Troilus and Criseyde by vectoring genre and character is to explore the parameters of the genres in play. In my Chaucer classes, I focus on four primary genres of Troilus and Criseyde: romance, epic, tragedy, and comedy. It is beyond the scope of this essay to delve into these individual genres in great depth, but by using such critical guides as Barry Windeatt's Troilus and Criseyde (1992) and Tony Davenport's Medieval Narrative: An Introduction (2004), professors can easily either assign readings or develop lectures that introduce students to the particular expectations of the necessary genres. (Additional studies of Chaucer and specific genres include works 
by Leonard 1981; Kendrick 1988; Crane 1994; Baswell 1995; Weisl 1995; and Kelly 1997.) Defining the genres can be as simple or as sophisticated as professors deem appropriate for their students. Some teachers may want to give expansive overviews of how these genres developed from their classical and contemporary antecedents; others may simply share with their students the most common characteristics and tropes of the genres in question.

All texts of a given genre include certain characteristics that thus constitute them as belonging to that genre, and so too do most genres include characters who behave in recognizable patterns. Despite the great variations between Odysseus and Aeneas, for example, they are both incontrovertibly epic heroes, and readers can readily delineate similarities between the two characters in their reactions to their respective narratival obstacles. Similarly, Guinevere in the Arthurian tradition and Bertilak's lady in Sir Gawain and the Green Knight fulfill the role of the courtly lady of romance in vastly different yet recognizably similar ways. In terms of teaching Troilus and Criseyde and returning to the example of Criseyde, one might then first ask students to examine her as a romance heroine rather than asking them either to analyze Troilus and Criseyde as a romance or Criseyde's character in light of her leaving Troilus for Diomede. How does she correspond--and how does she fail to correspond to--the expected parameters of the courtly lady of a medieval romance? In which books of Troilus and Criseyde does she most resemble a romance heroine, and in which books does she more resemble a heroine of a different genre? By helping students to see that characters and their actions are themselves functions of various genres, professors underscore that certain narratives virtually demand that their characters act within the prescribed range of actions typical of 
the genre. The simple question of whether a character follows or resists the expected behaviors of a particular genre allows deeper insights into both the character and the genres in play than analyzing the character's actions merely in terms of whether students think a character makes a "right" or "wrong" decision. By helping students to see that Criseyde is a romance heroine who is simultaneously like and unlike heroines of other generic and characterological traditions, professors highlight a more complex and vibrant view of the character than by focusing on genre or character alone.

As students read Troilus and Criseyde, I assign a highly artificial (yet, I hope, ultimately effective) task designed to help them perceive connections between characters and genres. They must “map” Troilus's, Criseyde's, and Pandarus's relationships to the four primary genres of romance, epic, tragedy, and comedy on three separate graphs, one for each character. On the graph's x-axis, the five books of Troilus and Criseyde are marked; on the y-axis, five notches are marked to indicate the extent to which a given genre is represented. For the y-axis, a zero represents that the character bears no connection to a given genre, whereas a five represents that the character appears to be fully embodying the typical behaviors of a character associated with that genre. I am purposefully vague about the values of the y-axis and use the numbers solely on a comparative basis. Obviously, a five registers a student's perception that a given character is more fully participating within the expectations of a given genre than a two, but I do not think it necessary to define precisely what a given character must do to merit a given number. The students can make such determinations for themselves at this point of the exercise. Thus, the students must plot out each primary character's relationship to the four genres of romance, epic, tragedy, and comedy for each of the five books of 
Troilus and Criseyde. To do so, they must think comparatively, determining book by book which genres are more or less in play than the other for each character. (For examples of students' graphs of Troilus and his relationship to genres, see Figures 1 and

\section{2.) [WHERE ARE THESE GRAPHS?]}

Obviously, a graph can by no means adequately capture the ways that Chaucer constructs his characters or his genres with such great sophistication and contradiction. Neither of the graphs in Figures 1 and 2 are in any manner meant to represent the "right" answer that students should seek to replicate; rather, these two graphs highlight that students disagree with one another greatly about how a given character reflects various generic traditions. However, by creating these graphs, students must produce a concrete, if initial, document reflecting the ways in which they perceive character and genre influencing each other. Thus, although this task is highly artificial in many ways--can the effects and techniques of literature truly be graphed? If they could be mapped, should they be?--the purpose of this part of the assignment is simply to encourage students to assess relationships between characters and genres and to make a provisional attempt to represent them in a manner such that they are visually apparent.

When creating these genre maps, students must also take notes regarding why they assign a given character and genre a particular value on the y-axis. For these notes, students could simply write down the line numbers relevant to their assertions or write brief essays, journal entries, or freewrites recording their reasoning process. If they see Criseyde as a primarily comic character in Book III but as more of a tragic character in Book IV, they should be able to point to the line numbers that support these interpretations, and they should thus be better prepared to consider her perplexing status 
in Book $\mathrm{V}$ as a function of these conflicting genres. These lists of line numbers build a body of evidence that can be used productively in subsequent class discussions and writing assignments.

Creating genre/character maps allows students to evaluate the degree to which a given genre appears to be in play in relationship to a given character within the relatively hermetic space of each of the narrative's five books. The graphs establish a useful foundation for small group work because students can be encouraged to discuss the creation of their individual graphs with one another. If one student sees Pandarus as more of a comic than tragic character in Book V but another student sees Pandarus's comic motivations as determinate to the poem's ambiguous resolution, their graphs will clearly demonstrate their interpretive differences and thus provide a readily visible starting point for a critical discussion. A simple teaching cue for a small group of students--find three points of greatest variance among your graphs and analyze why you individually came to such disparate conclusions about this character and genre--can stimulate a productive and student-led discussion of the text. This prompt also alleviates the tendency of students to feign agreement with one another in an effort to avoid any hint of conflict. Their maps record their varying textual interpretations in a non-confrontational manner, and continued discussion provides the surest way of understanding how these differences in perspective arose. A disheartening side-effect of postmodern theory's necessary intervention into epistemological certainty often arises in pedagogical situations when students assume any interpretation is as valid as another. By so clearly linking evidence to interpretation, this assignment helps students to build the necessary connections between textual evidence and literary interpretation. 
It should now be apparent that the graphs are a means of making readily visible the students' assessments of the vectored relationships between character and genre in Troilus and Criseyde, but the notes behind these graphs--the textual evidence that leads them to assign a particular value to a particular character and genre--are the real goal behind the exercise. By asking students to focus on genre and character and to plot out this relationship as meaningfully as possible, the professor creates a hermeneutic for interpretation coupled with a demand for close reading. Obviously, the graphs communicate very little without textual evidence to support their claims. By encouraging students to see the constitutive elements of multigeneric texts in harmony with other structural and theoretical components of the narrative, vectored analysis enlightens how texts function dynamically to create multiple meanings in harmony and in contradiction with one another.

The discussions that the graphs prompt provide a fertile field for essay assignments and exam questions. With graphs for each character and numerous points plotted on each graph marking the relationship between character and genre, ample material is generated for analysis and discussion for each book of Troilus and Criseyde as well as for the text as a whole. For example, students can be asked to analyze the ways in which a particular genre functions to establish expectations of behavior for the three characters in a given book of Troilus and Criseyde, or they could examine the ways in which multiple genres are necessary to explicate the actions of a given character in a given book. Additionally, students could trace one character's relationship to a particular genre across all of Troilus and Criseyde. By structuring analysis of Troilus and Criseyde through genre and character, professors focus their students' attention productively on the 
vectored intersection of two key hermeneutics, but the insights potentially gleaned from this combined perspective are virtually infinite. (See the appendix for additional suggestions for essay topics.)

A final benefit of this pedagogical approach to multigeneric texts is that it creates a common classroom foundation for analysis. Professors may select from a multitude of pedagogically sound approaches to Troilus and Criseyde--e.g., historicist, thematic, feminist, queer, psychoanalytical, New Critical--but by providing a foundation of analysis in genre and character, professors give their student a common vocabulary with which they can then proceed to analyze from additional perspectives. For example, a student writing a feminist analysis of Criseyde is somewhat likely to write an essay as I have described previously, one which selectively gathers evidence to support the writer's point of view but does not as successfully engage with textual moments problematic to the argument. If a teacher focuses students' attention on feminist theory, genre, and character, they are more likely to see the ways in which genres create and constrain a female character's actions, a critical revelation that is more powerful, I would argue, than an essay that in essence says, "It wasn't Criseyde's fault." Whether this observation is true or not seems to me much less interesting than the ways in which genre and character create a limited range of personality and action for this fascinating and enigmatic heroine.

I have focused exclusively on Troilus and Criseyde in this essay, but I am confident that this approach of vectoring analysis through genre and character could be successfully exported to address a wide range of multigeneric texts, from The Fairy Queen to Ulysses. Indeed, so many great works of literature play with multiple genres that this approach could likely be adapted to virtually any narrative. Professors of 
different literatures will need to adapt the basic structure of the graph to different genres and characters, of course, and they will need to change the $\mathrm{x}$ - and $\mathrm{y}$-axes of the graphs as well, in response to the text they are teaching. The basic structure of the genre map, as well as the ways in which it compels students to take detailed notes about the intersection of characters and genres, will nonetheless provide a solid pedagogical structure for many disparate texts and lessons.

Through the investigation of character and genre, students achieve a deeper critical appreciation of Troilus and Criseyde, but I hope they also find a deeper pleasure in the text as well. We read, study, and analyze texts for many reasons, but pleasure should not be denied as one of our primary motivations for turning and returning to particularly beloved narratives. As Aranye Fradenburg (2002: 246-47) poignantly observes, "The survival of the humanities in the academy depends on our power to provoke curiosity and wonder. Let's take more risk with our enjoyment, with the fact that what makes our work distinctive is precisely its foregrounding of enjoyment" (original emphasis). By helping our students to see the ways in which characters function in multigeneric texts, I hope that they attain a deeper critical understanding of Chaucer's Troilus and Criseyde, as well as a deeper pleasure in this most seductive of narratives.

\section{Acknowledgments}

I would like to thank the students of my Chaucer classes for their infectious enthusiasm, as well as Daren Hill for his technical expertise and intellectual inspiration. 


\section{Appendix: Suggested Essay Topics for Addressing Genre and Character in Troilus and Criseyde}

Our critical classroom discussions of Troilus and Criseyde have focused on the ways in which the characters of Troilus, Criseyde, and Pandarus reflect and participate in the generic traditions of romance, epic, tragedy, and comedy. For your essays, consider one of the following topics:

1. Examine one of these characters in one of the five books of Troilus and Criseyde. How are the generic traditions of romance, epic, tragedy, and comedy in play for this character? How do these genres help the reader to understand the character's actions? Develop a thesis that examines how one character's actions in one book of Troilus and Criseyde reflect a range of generic possibilities.

2. Of the four genres of romance, epic, tragedy, and comedy, explain how one of these genres most helps the reader to understand the actions of Troilus, Criseyde, or Pandarus throughout all of Troilus and Criseyde. For example, how does our understanding of Troilus change if we read him as an epic hero, or how does our understanding of Criseyde change if we read her as a comic heroine? Following the narrative trajectory of one character through the hermeneutic of one genre, develop a thesis exploring how this combination of character and genre influences your interpretation of Troilus and Criseyde.

3. Examine the genre maps that you have made charting the relationships between the characters and genres of Troilus and Criseyde. Locate a striking movement in one of the graphs between books of the text, and explain how and why Chaucer shifts the genres to such an extent. For example, if you notice that a character primarily reflects a tragic perspective in Book IV but then a comic perspective in Book V, you could theorize what Chaucer achieves through such a transition. 
4. As well as establishing narratival expectations, genres also establish expectations for the genders of their characters. For example, the masculinity of a romance hero is different than the masculinity of a tragic, epic, or comic protagonist. By examining the contours of the typical genders of a given genre, develop a thesis that explores how a character of Troilus and Criseyde adheres to or subverts the gendered expectations of behavior for a given genre.

5. Feel free to develop your own topics, but be sure to check them with me. Drop by office hours so that we can make sure you are on the right track.

\section{Works Cited}

Barr, Marleen S. 2000. Genre Fission: A New Discourse Practice for Cultural Studies. Iowa City: University of Iowa Press.

Barthes, Roland. 1975. The Pleasure of the Text. Trans. Richard Miller. New York: Hill and Wang.

Baswell, Christopher. 1995. Virgil in Medieval England: Figuring the Aeneid from the Twelfth Century to Chaucer. Cambridge: Cambridge University Press.

Beebee, Thomas D. 1994. The Ideology of Genre: A Comparative Study of Generic Instability. University Park: Pennsylvania State University Press.

Cixous, Hélène. 1974. “The Character of 'Character.”' Trans. Keith Cohen. New Literary History 5: 383-402.

Cohn, Dorrit. 1978. Transparent Minds: Narrative Modes for Presenting Consciousness in Fiction. Princeton, NJ: Princeton University Press. 
Colie, Rosalie. 2000. "Genre-Systems and the Functions of Literature.” In Duff 2000: $127-66$.

Crane, Susan. 1994. Gender and Romance in Chaucer's Canterbury Tales. Princeton, NJ: Princeton University Press.

Davenport, Tony. 2004. Medieval Narrative: An Introduction. Oxford: Oxford University Press.

Derrida, Jacques. 1992. “The Law of Genre.” In Acts of Literature, ed. Derek Attridge, 22-52. London: Routledge.

Devitt, Amy J. 2004. Writing Genres. Carbondale: Southern Illinois University Press. Dubrow, Heather. 1982. Genre. London: Methuen.

Duff, David. 2000. Modern Genre Theory. Harlow, England: Longman.

Forster, E. M. 1927. Aspects of the Novel. New York: Harcourt Brace.

Fowler, Elizabeth. 2003. Literary Character: The Human Figure in Early English Writing. Ithaca, NY: Cornell University Press.

Fradenburg, L.O. Aranye. 2002. Sacrifice Your Love: Psychoanalysis, Historicism, Chaucer.Minneapolis: University of Minnesota Press.

Kelly, Henry. 1997. Chaucerian Tragedy. Cambridge: D. S. Brewer.

Kendrick, Laura. 1988. Chaucerian Play: Comedy and Control in the Canterbury Tales. Berkeley: University of California Press.

Leonard, Frances McNeely. 1981. Laughter in the Courts of Love: Comedy in Allegory, from Chaucer to Spenser. Norman, OK: Pilgrim.

Lynch, Deirdre. 1998. The Economy of Characters: Novels, Market Culture, and the Business of Inner Meaning. Chicago, IL: University of Chicago Press. 
McAlpine, Monica. 1978. The Genre of Troilus and Criseyde. Ithaca: Cornell University Press.

Parisi, Peter. 1979. “Close Reading, Creative Writing, and Cognitive Development.” College English 41, no. 1: 57-67.

Phelan, James. 1989. Reading People, Reading Plots: Character, Progression, and the Interpretation of Narrative. Chicago, IL: University of Chicago Press.

Price, Martin. 1983. Forms of Life: Character and Moral Imagination in the Novel. New Haven, CT: Yale University Press,

Pugh, Tison. 2002. “Chaucer and Genre: A Teaching Model for the Upper-Level Undergraduate Course." Studies in Medieval and Renaissance Teaching 9, no. 2: 45-60.

Rorty, Amélie. 1988. “Characters, Person, Selves, Individuals.” In Mind in Action: Essays in the Philosophy of Mind, 78-98. Boston: Beacon.

Todorov, Tzvetan. 1990. Genres in Discourse. Trans. Catherine Porter. Cambridge: Cambridge University Press,

Weisl, Angela Jane. 1995. Conquering the Reign of Femeny: Gender and Genre in Chaucer's Romance. Cambridge: D. S. Brewer.

Windeatt, Barry. 1992. Troilus and Criseyde: Oxford Guides to Chaucer. Oxford: Clarendon. 